\title{
The Wall of Rhizobium leguminosarum in Bacteroid and Free-living Forms
}

\author{
By A. A. N. van BRUSSEL, K. PLANQUÉ AND A. QUISPEL \\ Research Group of Biological Nitrogen Fixation, Botanical \\ Laboratories, Nonnensteeg 3, Leiden, The Netherlands
}

(Received 5 January 1977)

\begin{abstract}
Walls of the bacteroid form of Rhizobium leguminosarum, from plant nodules, and walls of free-living $R$. leguminosarum were isolated and compared by extraction with aqueous phenol and chemical analysis. Bacteroid walls had less lipopolysaccharide than walls isolated from bacteria cultured on four different media. This difference may be relevant to the relatively greater permeability of the outer membrane of bacteroids, and important in symbiotic interactions.
\end{abstract}

\section{INTRODUCTION}

The symbiotic form of Rhizobium is responsible for nitrogen fixation in root nodules of leguminous plants, and occurs mainly as swollen pleomorphic forms called bacteroids. In contrast, free-living rhizobia are rod-shaped when grown on most media.

The wall of Gram-negative bacteria such as Rhizobium contains a rigid layer of mucopeptide with covalently linked lipoprotein. In addition, non-covalently bound to the rigid layer, there is an outer membrane composed of a complex of lipopolysaccharide, lipids, lipoproteins and proteins (Reaveley \& Burge, 1972).

The suggestion that the rhizobial wall is of significance in symbiosis is due to Schwinghamer (1968) and Jordan, Yamamura \& McKague (I969) and is supported by observations indicating that the bacteroid outer membrane is more permeable than that of the free-living bacteria. Thus, Rhizobium leguminosarum bacteroids are more sensitive to digestion with lysozyme than are free-living bacteria. Bacteroids are also much less resistant than bacteria to hydrolysis by trypsin, or treatment with sodium dodecyl sulphate, sodium deoxycholate, Triton X-Ioo or EDTA (van Brussel, I973, and unpublished observations). Further, in $R$. lupini, the bacteroids are more permeable to chloramphenicol than the corresponding bacterial form (Coventry \& Dilworth, 1975). Costerton, Ingram \& Cheng (1974) described similar observations for other bacteria with known defects in the outer membrane.

The composition of bacterial walls is affected by the composition of the growth medium (Ellwood \& Tempest, 1972). Studies of changes which occur in the composition of the wall during bacteroid formation may aid our understanding of several phenomena: for example, why bacteroids are pleomorphic; the interactions which occur through the complicated system of membranous layers which separate bacteroids from host cytoplasm; and the specific recognition sites present on the surface of Rhizobium (Dazzo \& Hubbell, 1975; Wolpert \& Albersheim, 1976; Planqué \& Kijne, 1977).

The present paper reports a comparison of the walls of bacteroids and bacteria of $R$. leguminosarum grown on four different media. It is shown that the lipopolysaccharide content of walls of bacteroids is different from that of walls of free-living bacteria. 


\section{METHODS}

Organisms and growth. Rhizobium leguminosarum Frank, strain AI7I (Allen, Hamatová \& Skinner, 1973) was grown on four different media which had the following compositions $(\%, w / v$, except where otherwise stated). Medium A (mannitol/glucose/yeast extract medium): mannitol, 0.35; glucose, I $\cdot 15$; $\mathrm{K}_{2} \mathrm{HPO}_{4}, 0.05 ; \mathrm{CaCO}_{3}, 0.001 ; \mathrm{MgSO}_{4} .7 \mathrm{H}_{2} \mathrm{O}, 0.02 ; \mathrm{NaCl}, 0.02$; yeast extract (see below), $10 \%(\mathrm{v} / \mathrm{v})$; $\mathrm{pH} 7.0$ [for maintenance of the organism, $\mathrm{I} \cdot 5 \%$ agar was added and $\mathrm{CaCO}_{3}$ was increased to $0.02 \%$ ]. Medium B (mannitol/nitrate medium): mannitol, I.4; $\mathrm{K}_{2} \mathrm{HPO}_{4}, 0.03 ; \mathrm{KH}_{2} \mathrm{PO}_{4}, 0 . \mathrm{I} ; \mathrm{MgSO}_{4} \cdot 7 \mathrm{H}_{2} \mathrm{O}, 0.055$; $\mathrm{Ca}\left(\mathrm{NO}_{3}\right)_{2} .4 \mathrm{H}_{2} \mathrm{O}, 0.13 ; \mathrm{KNO}_{3}, 0.055$; biotin, I $\mu \mathrm{g}$; trace element solution, $0.25 \%(\mathrm{v} / \mathrm{v}) ; \mathrm{pH} 6.0$. Medium $\mathrm{B}+\mathrm{Y}$ (mannitol/nitrate/yeast extract medium): as medium B, but with added yeast extract, $10 \%(\mathrm{v} / \mathrm{v})$. Medium $\mathrm{C}$ (mannitol/ammonium medium): mannitol, I.4; $\mathrm{K}_{2} \mathrm{HPO}_{4}, 0.06 ; \mathrm{KH}_{2} \mathrm{PO}_{4}, 0.04 ; \mathrm{CaCO}_{3}, 0.001$; $\mathrm{MgSO}_{4} .7 \mathrm{H}_{2} \mathrm{O}, 0.055 ; \mathrm{NH}_{4} \mathrm{Cl}, 0.3$; biotin, I $\mu \mathrm{g}$; trace element solution, $0.25 \%(\mathrm{v} / \mathrm{v}) ; \mathrm{pH} 7 \cdot 0$. Yeast extract was prepared by autolysing fresh baker's yeast: $20 \%(\mathrm{w} / \mathrm{v})$ yeast in water was incubated for $2 \mathrm{~h}$ at $60{ }^{\circ} \mathrm{C}$, then boiled for $15 \mathrm{~min}$, cooled, centrifuged, and the supernatant fluid was sterilized. Trace element solution contained $(\%, \mathrm{w} / \mathrm{v}): \mathrm{CuSO}_{4} .5 \mathrm{H}_{2} \mathrm{O}, 0.0035 ; \mathrm{MnSO}_{4} .4 \mathrm{H}_{2} \mathrm{O}, 0.06 \mathrm{I} ; \mathrm{ZnSO}_{4} .7 \mathrm{H}_{2} \mathrm{O}, 0.0097 ; \mathrm{H}_{3} \mathrm{BO}_{3}, 0.127$; $\mathrm{Na}_{2} \mathrm{MoO}_{4} .4 \mathrm{H}_{2} \mathrm{O}, 0.0398 ; \mathrm{FeSO}_{4} \cdot 7 \mathrm{H}_{2} \mathrm{O}$, I; EDTA, I.04; KOH, 0.68.

The bacteria were cultured at $25^{\circ} \mathrm{C}$ in $\mathrm{I} 1$ of medium $\mathrm{A}$ or $\mathrm{B}+\mathrm{Y}$ or in 151 of medium $\mathrm{B}$ or $\mathrm{C}$. The former were aerated by shaking on a gyratory shaker at $240 \mathrm{rev} . \mathrm{min}^{-1}$; the latter by bubbling humidified air.

Generation times in medium A or B $+\mathrm{Y}$ were $3 \pm 0.5 \mathrm{~h}$; and in medium B or $\mathrm{C}, 9.5 \pm 0.5 \mathrm{~h}$. Bacteria grown in medium $\mathrm{B}$ or $\mathrm{B}+\mathrm{Y}$ had the normal rod form. In medium $\mathrm{A}$ both normal and slightly swollen rods occurred, while in medium $\mathrm{C}$ most bacteria were irregularly shaped swollen rods. The $\mathrm{pH}$ of media $\mathrm{A}, \mathrm{B}$ and $\mathrm{B}+\mathrm{Y}$ remained constant during culture, but in medium $\mathrm{C}$ the $\mathrm{pH}$ had decreased to 5 by the time of harvest. Bacteria were harvested before the end of the exponential growth phase with a continuous flow centrifuge system at $31000 \mathrm{~g}$. They were washed twice in ice-cold water, frozen with liquid nitrogen, freezedried, and then stored at $-20^{\circ} \mathrm{C}$.

Pisum sativum L. var. Rondo (Cebeco, Rotterdam, Holland) was grown in tubes as described by Libbenga \& Harkes (1973) and watered with the nitrogen-free medium of Raggio \& Raggio (1956). Seeds were inoculated with $R$. leguminosarum strain AI7I before planting.

Preparation of bacteroids. Root nodules were detached from the roots and crushed in $0.3 \mathrm{M}$-sucrose at $4{ }^{\circ} \mathrm{C}$. The bacteroid fraction was purified by filtering through a coarse glass filter, centrifuging twice at I $100 \mathrm{~g}$ for $10 \mathrm{~min}$ in cold $0.3 \mathrm{M}$-sucrose, and then washing three times in cold distilled water to remove the sucrose. The bacteroid suspension so obtained contained at least $95 \%$ typical bacteroid forms and negligible traces of plant debris. The suspension was then treated and stored as described above for bacteria. Most bacteroid forms were up to three times larger than cultured forms, and were rods, $\mathrm{Y}$ - or X-shaped.

Wall isolation and purification. Walls were prepared by shaking a $3 \%(w / v)$ suspension of freeze-dried organisms in water with glass beads at below $6{ }^{\circ} \mathrm{C}$. The wall fraction was purified by centrifugation ( $12000 \mathrm{~g}, 10 \mathrm{~min}$ ) and resuspension in cold distilled water, repeated six times. The removal of nucleic acids and proteins in the supernatant fluid was followed by monitoring the ultraviolet absorption spectrum between 200 and $320 \mathrm{~nm}$. Contamination of walls was examined by electron microscopy after staining with uranyl acetate or neutral phosphotungstic acid. Wall contamination by membrane-bound enzymes was estimated by measuring the NADH oxidase activity (Osborn et al., 1972).

Phenol extraction. Walls were extracted three times with $90 \%(\mathrm{w} / \mathrm{v})$ phenol $/$ water at 68 to $70{ }^{\circ} \mathrm{C}$ (Westphal, Lüderitz \& Bister, 1952). The aqueous and phenolic phases were separated by cooling to $0{ }^{\circ} \mathrm{C}$ and centrifuging. The fractions were dialysed against distilled water, freeze-dried and weighed (Wardlaw, 1963; Clarke, Gray \& Reaveley, $1967 a, b, c)$. The quantity of walls extracted was at least $25 \mathrm{mg}$.

Analytical procedures. Carbohydrate was determined with anthrone reagent (Trevelyan \& Harrison, 1952) using D-glucose as standard; protein, by the method of Lowry et al. (195I), with bovine serum albumin as standard; heptose, with Dische's cysteine $/ \mathrm{H}_{2} \mathrm{SO}_{4}$ reagent as modified by Osborn (1963) using D-glucoheptose as standard; and poly- $\beta$-hydroxybutyrate, according to Law \& Slepecky (I96I).

\section{RESULTS}

\section{Purity of wall preparations}

Wall preparations always showed some contaminating material when examined by light or electron microscopy. Walls were transparent under phase contrast microscopy, and contaminating material could be seen within the wall husks and suspending fluid. Contamination was also visible by electron microscopy. No obvious differences in the degree of contamination between bacterial and bacteroid walls was observed. 
Table I. Fractions obtained by phenol extraction of walls of bacterial and bacteroid forms of $R$. leguminosarum

Results are expressed as percentage dry weight.

Fractions obtained on extraction of wall preparations with aqueous phenol

Source of walls

Bacteria grown in:

Medium A

Medium B

Medium B + Y

Medium C

Bacteroids

\begin{tabular}{|c|c|c|c|}
\hline $\begin{array}{l}\text { Aqueous } \\
\text { phase }\end{array}$ & $\begin{array}{c}\text { Phenolic } \\
\text { phase }\end{array}$ & $\begin{array}{l}\text { Insoluble } \\
\text { residue }\end{array}$ & Recovery \\
\hline $14 \cdot 5 \pm I \cdot 8$ & $26 \cdot 8 \pm 2 \cdot 2$ & $53 \cdot 2 \pm 2.9$ & $94 \cdot I \pm 3 \cdot 7$ \\
\hline $2 I \cdot 6 \pm 2 \cdot 8$ & $22 \cdot 8 \pm 2.9$ & $45 \cdot 8 \pm 2 \cdot 5$ & $89.9 \pm 2.0$ \\
\hline $23 \cdot 6 \pm I \cdot 2$ & $22 \cdot 0 \pm 1 \cdot 0$ & $46 \cdot 8 \pm 0 \cdot 2$ & $92 \cdot 5 \pm 0.3$ \\
\hline $8 \cdot 2 \pm 3 \cdot 2$ & $26 \cdot 2 \pm 2 \cdot I$ & $55.8 \pm 2.9$ & $90 \cdot 4 \pm 1 \cdot 4$ \\
\hline $2 \cdot \mathrm{I} \pm \mathrm{I} \cdot 5$ & $22 \cdot 9 \pm 2 \cdot 6$ & $64 \cdot 2 \pm 13 \cdot 4$ & $88 \cdot 0 \pm 10 \cdot 0$ \\
\hline
\end{tabular}

NADH oxidase activity (a cytoplasmic membrane marker) of wall preparations was Io to $15 \%$ of the total activity of extracts. Further washing of the walls did not decrease this activity which was attributed to tightly-bound fragments of cytoplasmic membrane. Wall preparations from organisms grown in medium $\mathrm{C}$ had no detectable NADH oxidase activity. Poly- $\beta$-hydroxybutyrate, which is phenol soluble (Vincent, Humphrey \& North, I962), comprised less than $3 \%$ of the material in the phenol extracts from wall preparations and less than $0.3 \%$ of the phenol-insoluble residue.

\section{Controls on the production of artefacts}

The possibility that alterations in the composition of the walls might occur during isolation of the bacteroids was tested by incubating bacterial walls in a cell- and bacteroidfree nodule homogenate for $30 \mathrm{~min}$ at $0^{\circ} \mathrm{C}$. No differences were found between the phenol extracts of incubated walls and unincubated walls isolated from organisms grown in medium $\mathrm{B}+\mathrm{Y}$. Thus, if changes in bacteroid walls occur during isolation from nodules, they are caused by a sensitivity of bacteroid walls to nodule factors different from that of walls of bacteria grown in medium $\mathrm{B}+\mathrm{Y}$.

\section{Extraction of wall preparations with aqueous phenol}

Walls of bacteria can be separated into three fractions after extraction with aqueous phenol: lipopolysaccharide remains in the aqueous phase; non-covalently bound protein together with lipoprotein is extracted into the phenolic phase; and the mucopeptidelipoprotein complex is found in the insoluble residue of the interface and also in the pellet obtained on centrifuging.

Extraction of walls of bacteroids and bacteria grown in medium $\mathrm{C}$ or $\mathrm{A}$ resulted in a scarcely visible interface. However, with walls from organisms grown in medium $\mathrm{B}$ or $\mathrm{B}+\mathrm{Y}$, some insoluble material remained at the interface even after the third extraction. The dialysed and freeze-dried material from the phenolic phase was brown and that from the aqueous phase white, irrespective of the source of the walls. The insoluble residue of mucopeptide-lipoprotein was compact and white when isolated from walls of organisms grown in medium $\mathrm{A}, \mathrm{B}$ or $\mathrm{B}+\mathrm{Y}$, but grey and less compact from walls of organisms grown in medium $\mathrm{C}$.

Bacteroid walls gave less material in the aqueous phase and more insoluble residue than bacterial walls (Table I). The amount of material in the phenolic phase from both bacteria and bacteroids was approximately the same. There was no significant difference in the recovery of material. The amount of material in the aqueous phase from walls of bacteria cultured on a given medium was fairly constant; there was some variation between media, but amounts were never as low as those obtained from bacteroid walls.

Differences in the amount of material extracted into the aqueous phase are consistent 
Table 2. Composition of walls and aqueous phase material extracted from walls of bacterial and bacteroid forms of $R$. leguminosarum

\begin{tabular}{|c|c|c|c|c|}
\hline \multirow[b]{2}{*}{ Source of walls } & \multicolumn{3}{|c|}{ Wall composition $(\%$ dry wt) } & \multirow{2}{*}{$\begin{array}{l}\text { Heptose in } \\
\text { aqueous phase } \\
\text { material } \\
(\% \text { dry wt })\end{array}$} \\
\hline & Carbohydrate & Protein & Heptose & \\
\hline \multicolumn{5}{|l|}{ Bacteria grown in: } \\
\hline Medium A & $2 \cdot 4$ & $66 \cdot 7$ & $1 \cdot 0$ & $4 \cdot 8$ \\
\hline Medium B & $3 \cdot 6$ & $59 \cdot \mathrm{I}$ & $1 \cdot 7$ & $5 \cdot 3$ \\
\hline Medium B + Y & $3 \cdot 7$ & $57 \cdot 3$ & $I \cdot 9$ & ND \\
\hline Medium C & $2 \cdot 3$ & $72 \cdot 8$ & 0.8 & $5 \cdot 3$ \\
\hline Bacteroids & $\mathrm{I} \cdot 8$ & $72 \cdot 9$ & 0.4 & $3 \cdot 5$ \\
\hline
\end{tabular}

ND, Not determined. Values are the mean of at least two estimations.

with differences in the quantity or the solubility properties of the lipopolysaccharide (Galanos, Lüderitz \& Westphal, 1969). The presence of lipopolysaccharide in the aqueous phase was confirmed by the Dische reaction, which showed an absorption spectrum consistent with the presence of heptose, a constituent of lipopolysaccharide. Material of the aqueous phase contained proportionately more heptose than did the wall (Table 2).

Changes in the total amount of heptose in a particular wall preparation and in material extracted into the aqueous phase corresponded to changes in the total amount of carbohydrate (Table 2). This correlation is in agreement with differences in the lipopolysaccharide component of bacterial and bacteroid walls.

\section{DISCUSSION}

The contamination by non-cell wall material did not significantly affect the estimations of the components of different wall preparations, hence if changes in the composition of bacteroid walls occur during isolation from nodules, they must be attributed to intrinsic properties of the wall. Since bacteroid walls give less material in the aqueous phase on extraction with aqueous phenol, and have lower carbohydrate and heptose contents than bacterial walls, we suppose that these factors may account for the greater permeability of bacteroid walls.

Walls from bacteria grown in medium $\mathrm{A}$ and, especially, in medium $\mathrm{C}$ had less heptose and less material was extracted from them into the aqueous phase than walls from bacteria grown in medium B or medium B + Y. Organisms from the latter media were morphologically normal, whereas those from medium $A$ and, especially, medium $\mathbf{C}$ were aberrant, as noted for growth on unbalanced media by Jordan \& Coulter (1965) and by Sherwood (1972). These aberrant forms are probably caused by fragmentation of the rigid layer of the wall and subsequent bulging produced by osmotic pressure. Fragmentation of the rigid layer reduces the retention of outer membrane components such as lipopolysaccharide (Hofschneider \& Martin, 1968) with a concomitant increase in permeability for molecules such as lysozyme (Burman, Nordstrom \& Bloom, 1972). This may be why bacteria grown in medium $\mathrm{A}$ and, probably, in medium $\mathrm{C}$ are more sensitive to lysozyme than bacteria grown in medium B or B $+\mathrm{Y}$ (van Brussel, I973). This may also be true for bacteroids, which have very little aqueous phase material and heptose in their walls, and are extremely sensitive to treatment with lysozyme (van Brussel, I973).

Alternatively, bacteroid lipopolysaccharide may be organized as in some rough bacterial strains where truncated lipopolysaccharide molecules contribute less to the dry weight of the wall. Further, as with some rough bacteria, the lipopolysaccharide may not be totally recovered in the aqueous phase on phenol extraction because of its increased hydrophobicity (Galanos et al., 1969). Another similarity of bacteroids with rough bacteria 
is their greater permeability compared with smooth bacterial forms (Tamaki, Sato \& Matsuhashi, 1971).

In conclusion, the differences we have found in composition between the walls of bacterial and bacteroid forms may be due to bacteroids having less lipopolysaccharide in their walls than bacteria. However, the data do not exclude the possibilities that bacteroids may have a rough and bacteria a smooth-type lipopolysaccharide in their walls, or that bacteroids may have a more loosely bound lipopolysaccharide than bacteria which is lost during the isolation procedures.

We thank Annelies Burgers and Mr J. van Nierop for excellent technical assistance. Part of this work was subsidized by the Foundation for Fundamental Biological Research (BION).

\section{REFERENCES}

Allen, O. N., Hamatová, E. \& Skinner, F. A. (1973). IBP World Catalogue of Rhizobium Collections, p. I I I. Edited by F. A. Skinner. London: IBP Central Office.

Brussel, A. A. N. van (1973). Ph.D. thesis, University of Leiden, The Netherlands.

Burman, L. G., Nordstrom, K. \& Bloom, G. D. (1972). Murein and the outer penetration barrier of Escherichia coli $\mathrm{K}-\mathrm{I} 2$, Proteus mirabilis and Pseudomonas aeruginosa. Journal of Bacteriology II2, 1364-1374.

Clarke, K., Gray, G. W. \& Reaveley, D. A. (I967a). The cell walls of $P$ seudomonas aeruginosa. General composition. Biochemical Journal ro5, 749-754.

Clarke, K., Gray, G. W. \& Reaveley, D. A. $(1967 b)$. The extraction of cell walls of Pseudomonas aeruginosa with aqueous phenol. Material from the phenol layer. Biochemical Journal ro5, $755^{-758 .}$

Clarke, K., Gray, G. W. \& Reaveley, D. A. $(1967 c)$. The extraction of cell walls of Pseudomonas aeruginosa with aqueous phenol. The insoluble residue and material from the aqueous layers. Biochemical Journal ro5, 759-765.

Costerton, J. W., Ingram, J. M. \& Cheng, K.-J. ( I 974). Structure and function of the cell envelope of gram-negative bacteria. Bacteriological Reviews 38, 87-I IO.

Coventry, D. R. \& Dilworth, M. J. (1975). Inhibition of protein synthesis by D-threo-chloramphenicol in the laboratory and nodule forms of Rhizobium lupini. Journal of General Microbiology 9o, 69-75.

Dazzo, F. B. \& Hubbell, D. H. (1975). Crossreactive antigens and lectin as determinants of symbiotic specificity in the Rhizobium-clover association. Applied Microbiology 30, 1017I033.

Ellwood, D. C. \& Tempest, D. W. (I972). Effects of environment on bacterial wall and composition. In Advances in Microbial Physiology, pp. 83-1 I7. Edited by A. H. Rose and D.W. Tempest. London and New York: Academic Press.

Galanos, C., Lüderitz, O. \& Westphal, O. ( 1969 ). A new method for the extraction of R-lipopolysaccharides. European Journal of Biochemistry $\mathbf{9}$, $245^{-2} 49$.

Hofschneider, P. H. \& MARTiN, H. H. (Ig68).
Diversity of surface layers in L-forms of Proteus mirabilis. Journal of General Microbiology 5I, 23-33.

Jordan, D. C. \& Coulter, W. H. (ig65). On the cytology and synthetic capacities of natural and artificially produced bacteroids of Rhizobium leguminosarum. Canadian Journal of Microbiology II, 709-720.

Jordan, D. C., Yamamura, Y. \& MCKague, M. E. (1969). Mode of action of viomycin on Rhizobium meliloti. Canadian Journal of Microbiology $\mathbf{1 5}$, IO05-IOI 2.

LAw, J. H. \& Slepecky, R. A. (I96I). Assay of poly- $\beta$-hydroxybutyric acid. Journalof Bacteriology 82, 33-36.

Libbenga, K. R. \& Harkes, P. A. A. (1973). Initial proliferation of cortical cells in the formation of root nodules in Pisum sativum L. Planta 114, 17-28.

Lowry, O. H., Rosebrough, N. J., Farr, A. L. \& RANDALl, R. J. (I95I). Protein measurement with the Folin phenol reagent. Journal of Biological Chemistry 193, 265-275.

OSBORN, M. J. (I963). Studies on the gram-negative cell wall. I. Evidence for the role of 2-keto-3deoxyoctonate in the lipopolysaccharide of Salmonella typhimurium. Proceedings of the National Academy of Sciences of the United States of America 5o, 499-506.

Osborn, M. J., Gander, J. E., Parisi, F. \& Carson, J. (1972). Mechanism of assembly of the outer membrane of Salmonella typhimurium. Journal of Biological Chemistry 247, 3962-3973.

Planqué, K. \& KiJne, J. W. (I977). The presence of a glycan type polysaccharide in the cell walls of Rhizobium leguminosarum. FEBSLetters 73, 64-66.

RagGio, M. \& RagGio, N. (1956). Relation entre cotiledones y nodulation y factores que la afectan. Phyton 7, 103-119.

Reaveley, D. A. \& Burge, R. E. (1972). Walls and membranes in bacteria. In Advances in Microbial Physiologv, pp. I-8I. Edited by A. H. Rose and D. W. Tempest. London and New York: Academic Press.

SCHWinghamer, E. A. (I968). Loss of effectiveness and infectivity in mutants of Rhizobium resistant to metabolic inhibitors. Canadian Journal of Microbiology 14, 355-367. 
SHERwOOD, M. T. (1972). Inhibition of Rhizobium trifolii by yeast extracts or glycine is prevented by calcium. Journal of General Microbiology 7I, 35I-358.

Tamaki, S., Sato, T. \& Matsuhashi, M. (I97I). Role of lipopolysaccharides in antibiotic resistance and bacteriophage adsorption of Escherichia coli K-I 2. Journal of Bacteriology ro5, 968-975.

Trevelyan, W. E. \& Harrison, J. S. (I952). Studies on yeast metabolism. I. Fractionation and microdetermination of cell carbohydrates. Biochemical Journal 50, 298-303.

Vincent, J. M., Humphrey, B. \& North, R. J. (1962). Some features of the fine structure and chemical composition of Rhizobium trifolii. Journal of General Microbiology 29, 55I-555.
Wardlaw, A. C. (1963). The complement-dependent bacteriolytic activity of normal human serum. II. Cell wall composition of sensitive and resistant strains. Canadian Journal of Microbiology 9, 4I-52.

WestPhal, O., Lüderitz, O. \& Bister, F. (I952). Über die Extraktion von Bakterien mit Phenol/ Wasser. Zeitschrift für Naturforschung $7 \mathbf{B}$, I48- $^{-}$ I 55 .

Wolpert, J. S. \& Albersheim, P. (1976). Hostsymbiont interactions. I. The lectins of legumes interact with the O-antigen-containing lipopolysaccharides of their symbiont rhizobia. Biochemical and Biophysical Research Communications 70, 729-737. 